\title{
Atomic Layer Deposition of Photoconductive Cu2O Thin Films
}

\author{
livonen, Tomi
}

2019-06

livonen , T, Heikkilä , M J, Popov , G, Nieminen , H-E , Kaipio , M , Kemell , M , Mattinen , M, Meinander , K, Mizohata , K, Räisänen , J , Ritala , M \& Leskelä , M 2019 , ' Atomic Layer Deposition of Photoconductive Cu2O Thin Films ' , ACS Omega , vol. 4 , no. 6 , pp. 11205-11214 . https://doi.org/10.1021/acsomega.9b01351

http://hdl.handle.net/10138/304671

https://doi.org/10.1021/acsomega.9b01351

cc_by

publishedVersion

Downloaded from Helda, University of Helsinki institutional repository.

This is an electronic reprint of the original article.

This reprint may differ from the original in pagination and typographic detail.

Please cite the original version. 


\title{
Atomic Layer Deposition of Photoconductive $\mathrm{Cu}_{2} \mathrm{O}$ Thin Films
}

\author{
Tomi Iivonen, ${ }^{* \dagger}$ Mikko J. Heikkilä, ${ }^{\dagger}$ Georgi Popov, ${ }^{\dagger}$ Meta-Elisa Nieminen, ${ }^{\dagger}$ Mikko Kaipio, ${ }^{\dagger}$ \\ Marianna Kemell, ${ }^{\dagger}$ Miika Mattinen, ${ }^{\dagger}$ (i) Kristoffer Meinander, ${ }^{\ddagger}$ Kenichiro Mizohata, ${ }^{\ddagger}$ Jyrki Räisänen, ${ }^{\ddagger}$
} Mikko Ritala, ${ }^{\dagger}$ a and Markku Leskelä ${ }^{\dagger}$

${ }^{\dagger}$ Department of Chemistry, University of Helsinki, P.O. Box 55, FI-00014 Helsinki, Finland

Department of Physics, University of Helsinki, P.O. Box 43, FI-00014 Helsinki, Finland

\section{Supporting Information}

ABSTRACT: Herein, we report an atomic layer deposition (ALD) process for $\mathrm{Cu}_{2} \mathrm{O}$ thin films using copper(II) acetate $\left[\mathrm{Cu}(\mathrm{OAc})_{2}\right]$ and water vapor as precursors. This precursor combination enables the deposition of phasepure, polycrystalline, and impurity-free $\mathrm{Cu}_{2} \mathrm{O}$ thin films at temperatures of $180-220{ }^{\circ} \mathrm{C}$. The deposition of $\mathrm{Cu}(\mathrm{I})$ oxide films from a $\mathrm{Cu}$ (II) precursor without the use of a reducing agent is explained by the thermally induced reduction of $\mathrm{Cu}(\mathrm{OAc})_{2}$ to the volatile copper(I) acetate, CuOAc. In addition to the optimization of ALD process parameters and characterization of film properties, we studied the $\mathrm{Cu}_{2} \mathrm{O}$ films in the fabrication of photoconductor devices. Our proof-of-concept devices show that approx-

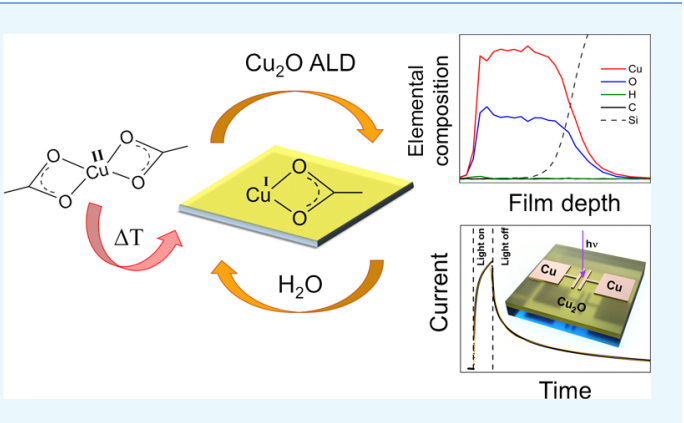
imately $20 \mathrm{~nm}$ thick $\mathrm{Cu}_{2} \mathrm{O}$ films can be used for photodetection in the visible wavelength range and that the thin film photoconductors exhibit improved device characteristics in comparison to bulk $\mathrm{Cu}_{2} \mathrm{O}$ crystals.

\section{INTRODUCTION}

Copper(I) oxide $\left(\mathrm{Cu}_{2} \mathrm{O}\right)$ is a p-type semiconductor material that crystallizes in a simple cubic structure. ${ }^{1}$ The p-type conductivity of $\mathrm{Cu}_{2} \mathrm{O}$ originates from intrinsic $\mathrm{Cu}$ vacancies in the crystal lattice, which facilitates the formation of acceptor levels approximately $0.25-0.45 \mathrm{eV}$ above the valence band maximum. $^{2,3}$ Other properties of $\mathrm{Cu}_{2} \mathrm{O}$ related to its semiconducting character include an optical band gap of 2.1-2.2 eV for the bulk material, ${ }^{4,5}$ a high absorption coefficient in the visible wavelength range, ${ }^{4}$ hole mobility ranging from 40 to $120 \mathrm{~cm}^{2} /(\mathrm{V} \mathrm{s})$, and electron diffusion length reaching up to $5 \mu \mathrm{m}$. ${ }^{6-11}$ Moreover, $\mathrm{Cu}_{2} \mathrm{O}$ is nontoxic, low-cost, and consists of earth-abundant elements. Due to this favorable combination of chemical, electronic, and optical properties, $\mathrm{Cu}_{2} \mathrm{O}$ has been studied for a wide range of applications, including heterojunction ${ }^{12,13}$ and homojunction solar cells, ${ }^{14,15}$ photoelectrochemical water splitting, ${ }^{16,17}$ thin film transistors, ${ }^{10,18}$ nonvolatile memories, ${ }^{19,20}$ photodiodes, and photoconductors. ${ }^{11,21-23}$ Furthermore, copper(I)-based ternary oxides, such as $\mathrm{CuAlO}_{2}{ }^{24}$ and $\mathrm{SrCu}_{2} \mathrm{O}_{2}{ }^{25}$ are promising candidates for transparent p-type conductive oxides, $^{26}$ and delafossite class $\mathrm{CuMO}_{2}(\mathrm{M}=\mathrm{Ta}, \mathrm{Fe}, \mathrm{V})$ compounds show promise in solar energy applications. ${ }^{27}$ Consequently, several methods have been developed for synthesizing $\mathrm{Cu}_{2} \mathrm{O}$ and for modifying its chemical, electronic, and optical properties. These methods include solvothermal methods, ${ }^{28}$ electrodeposition, ${ }^{14,16,29}$ sol-gel synthesis, ${ }^{30}$ thermal oxidation of copper, ${ }^{4,5,31}$ sputtering, ${ }^{2,7}$ chemical vapor deposition (CVD),,$^{32-34}$ and atomic layer deposition (ALD). ${ }^{23,35-39}$ From these methods, the solvothermal approach produces freestanding, one-dimensional $\mathrm{Cu}_{2} \mathrm{O}$ nanostructures, whereas the rest of the techniques are better suited for synthesizing $\mathrm{Cu}_{2} \mathrm{O}$ thin films. Among the thin film synthesis methods, ALD stands out due to its unique ability to produce conformal, high-quality and pinhole-free films uniformly on large area substrates. ${ }^{40,41}$

The ability of ALD to produce high-quality thin films originates from a deposition mechanism where the film growth proceeds via saturative and self-limiting surface reactions between alternately supplied gaseous precursors. ${ }^{42}$ This concept enables several unique features, such as control of film thickness on a subnanometer level, fabrication of nanolaminates, flexible introduction of dopants, ${ }^{43}$ and the deposition of conformal films on three-dimensional structures, such as high aspect ratio vias and trenches. ${ }^{40,44}$ Previous reports on ALD of $\mathrm{Cu}_{2} \mathrm{O}$ have been based on the use of $\mathrm{CuCl}$ $+\mathrm{H}_{2} \mathrm{O}{ }^{35}\left({ }^{n} \mathrm{Bu}_{3} \mathrm{P}\right)_{2} \mathrm{Cu}(\mathrm{acac})+\mathrm{H}_{2} \mathrm{O} / \mathrm{O}_{2}(\mathrm{Bu}=$ butyl, acac $=$ acetylacetonate $),{ }^{36} \mathrm{Cu}(\mathrm{dmamb})_{2}+\mathrm{H}_{2} \mathrm{O}(\mathrm{dmamb}=1-$ dimethylamino-2-methyl-2-butoxy),,$^{23,37,38}$ and $\mathrm{Cu}(\text { dmap })_{2}+$ $\mathrm{H}_{2} \mathrm{O}$ (dmap = 1-dimethylamino-2-propoxide). ${ }^{39}$ The deposition process based on $\mathrm{CuCl}+\mathrm{H}_{2} \mathrm{O}$ is limited to temperatures of $350{ }^{\circ} \mathrm{C}$ and higher as $\mathrm{CuCl}$ needs to be heated to $340{ }^{\circ} \mathrm{C}$ to obtain sufficient vapor pressure for gas phase deposition. It was also noted that this deposition process is not suitable for obtaining phase-pure $\mathrm{Cu}_{2} \mathrm{O}$ films due to the reductive thermal decomposition of $\mathrm{CuCl}$ that leads to the formation of metallic

Received: May 10, 2019

Accepted: June 6, 2019

Published: June 27, 2019 
copper in the films. ${ }^{35}$ In the case of the $\left({ }^{n} \mathrm{Bu}_{3} \mathrm{P}\right)_{2} \mathrm{Cu}($ acac $)+$ $\mathrm{H}_{2} \mathrm{O} / \mathrm{O}_{2}$ process, film deposition was achieved at significantly lower temperatures, $110-130{ }^{\circ} \mathrm{C} .{ }^{36}$ This deposition process exhibited good ALD characteristics, especially on $\mathrm{SiO}_{2}$ substrates. Further improvement in ALD of $\mathrm{Cu}_{2} \mathrm{O}$ was achieved using an aminoalkoxide copper precursor, $\mathrm{Cu}$ $(\mathrm{dmamb})_{2}$, in combination with water vapor. ${ }^{37}$ The optimal deposition temperature for this process with respect to saturation, film crystallinity, and surface roughness was shown to be $140-160{ }^{\circ} \mathrm{C}$. Films deposited from $\mathrm{Cu}(\mathrm{dmamb})_{2}$ and $\mathrm{H}_{2} \mathrm{O}$ were polycrystalline, phase-pure $\mathrm{Cu}_{2} \mathrm{O}$ and contained negligible amounts of carbon and nitrogen impurities as analyzed using X-ray diffraction (XRD) and Rutherford backscattering spectrometry. In addition, the $\mathrm{Cu}_{2} \mathrm{O}$ films deposited using the $\mathrm{Cu}(\mathrm{dmamb})_{2}+\mathrm{H}_{2} \mathrm{O}$ process had a direct allowed optical band gap value of $2.52 \mathrm{eV}$ and hole mobility of $8.05 \mathrm{~cm}^{2} / \mathrm{V} .^{37}$ Finally, another aminoalkoxide copper(II) compound, $\mathrm{Cu}(\mathrm{dmap})_{2}$, was used with water vapor at $110-$ $200^{\circ} \mathrm{C}^{39}$ The focus of this study was the deposition and characterization of $5 \mathrm{~nm}$ thick films using quartz crystal microbalance (QCM), X-ray diffraction, and X-ray photoelectron spectroscopy (XPS) techniques. $\mathrm{Cu}_{2} \mathrm{O}$ films deposited using the $\mathrm{Cu}(\mathrm{dmap})_{2}+\mathrm{H}_{2} \mathrm{O}$ process were reported to be X-ray amorphous and to oxidize upon exposure to air, which was attributed to the small thickness of the films. Interestingly, for both the $\mathrm{Cu}(\mathrm{dmamb})_{2}+\mathrm{H}_{2} \mathrm{O}$ and the $\mathrm{Cu}(\mathrm{dmap})_{2}+\mathrm{H}_{2} \mathrm{O}$ processes, the obtained films were of the $\mathrm{Cu}(\mathrm{I})$ oxide $\left(\mathrm{Cu}_{2} \mathrm{O}\right)$ phase even though the oxidation state of copper in these precursors is +2 . This implies that copper is reduced during the deposition process. In CVD experiments based on aminoalkoxide copper precursors, the reducing agent was identified to be the aminoalkoxide ligand. ${ }^{45,46}$ Therefore, it is conceivable that hydrogenated aminoalkoxide ligands can act as in situ formed reducing agents in ALD as well. However, this reaction mechanism has not been verified experimentally. ${ }^{39}$

In this study, we have used copper(II) acetate, $\mathrm{Cu}(\mathrm{OAc})_{2}$, in ALD to deposit $\mathrm{Cu}_{2} \mathrm{O}$ thin films. $\mathrm{Cu}(\mathrm{OAc})_{2}$ is a commercially available bulk chemical that exists both in the hydrated form, $\mathrm{Cu}(\mathrm{OAc})_{2} \cdot \mathrm{H}_{2} \mathrm{O}$, as well as in the anhydrous form. ${ }^{47}$ In the solid state, both the hydrated form and the anhydrous variant exist as dimers. ${ }^{48}$ A clear advantage of using copper(II) acetate in $\mathrm{Cu}_{2} \mathrm{O}$ film deposition is the low cost of the precursor, in particular if the hydrated variant is considered.

Heating hydrated $\mathrm{Cu}(\mathrm{OAc})_{2} \cdot \mathrm{H}_{2} \mathrm{O}$ to approximately $110-$ $160{ }^{\circ} \mathrm{C}$ results in the loss of water of crystallization and the subsequent formation of anhydrous $\mathrm{Cu}(\mathrm{OAc})_{2} \cdot{ }^{47,49} \mathrm{At}$ temperatures where volatilization starts to occur, the thermal properties of $\mathrm{Cu}(\mathrm{OAc})_{2}$ are complicated by both the reduction of copper and the formation of cluster molecules in the gas phase. $^{50}$ A thermogravimetric study performed under a dynamic $\mathrm{N}_{2}$ atmosphere showed that heating $\mathrm{Cu}(\mathrm{OAc})_{2}$ to $200{ }^{\circ} \mathrm{C}$ in oxygen-free conditions results in the reduction of copper from $\mathrm{Cu}^{2+}$ to $\mathrm{Cu}^{+}$and the evaporation of copper(I) acetate, $\mathrm{CuOAc}^{47}$ The reduction of $\mathrm{Cu}(\mathrm{OAc})_{2}$ to $\mathrm{CuOAc}$ upon heating in vacuo was observed also in another thermogravimetric study. ${ }^{51}$ There, it was also noted that the residue of heated $\mathrm{Cu}(\mathrm{OAc})_{2}$ contained both $\mathrm{Cu}_{2} \mathrm{O}$ and metallic $\mathrm{Cu}$. This indicates that the reduction of $\mathrm{Cu}(\mathrm{OAc})_{2}$ to $\mathrm{CuOAc}$ is likely to proceed via a two-stage, solid state comproportionation reaction. In the first stage, $\mathrm{Cu}(\mathrm{OAc})_{2}$ is partially decomposed to form metallic copper

$$
\begin{aligned}
\mathrm{Cu}(\mathrm{OAc})_{2}(\mathrm{~s}) \rightarrow & \mathrm{Cu}^{0}(\mathrm{~s}) \\
& + \text { acetate decomposition products }(\mathrm{g})
\end{aligned}
$$

The in situ formed metallic copper then reacts with $\mathrm{Cu}(\mathrm{OAc})_{2}$ and volatile $\mathrm{CuOAc}$ is formed via comproportionation

$$
\mathrm{Cu}(\mathrm{OAc})_{2}(\mathrm{~s})+\mathrm{Cu}^{0}(\mathrm{~s}) \rightarrow 2 \mathrm{CuOAc}(\mathrm{g})
$$

The existence of this reaction pathway is supported by the fact that $\mathrm{CuOAc}$ can be obtained from $\mathrm{Cu}(\mathrm{OAc})_{2}$ by heating the latter to $180-190{ }^{\circ} \mathrm{C}$ together with copper dust in reduced pressure. ${ }^{52}$ If $\mathrm{Cu}(\mathrm{OAc})_{2}$ is heated to $290{ }^{\circ} \mathrm{C}$ and above in oxygen-free conditions, complete decomposition of the compound occurs ${ }^{47}$ and results in the formation of metallic copper and volatile species deriving from the acetate ligand, such as acetic acid, acetone carbon dioxide, and water. ${ }^{53}$

The reduction of $\mathrm{Cu}(\mathrm{OAc})_{2}$ to $\mathrm{CuOAc}$ has also been shown to occur by means of mass spectroscopy. ${ }^{50}$ In an extensive study by Didonato and Busch, it was demonstrated that a majority of the volatile species forming from $\mathrm{Cu}(\mathrm{OAc})_{2}$ contain copper as $\mathrm{Cu}^{+}$, which is in agreement with the findings of the thermogravimetric experiments described in the literature. ${ }^{47,51}$ The mass spectrometric study also established that volatile copper(I) species that result from heating $\mathrm{Cu}(\mathrm{OAc})_{2}$ form cluster molecules that contain either two, three, or four copper atoms. ${ }^{50}$ This implies that $\mathrm{CuOAc}$ species in the gas phase are either dimeric, trimeric, or tetrameric. In the context of ALD, the thermally induced reduction of $\mathrm{Cu}(\mathrm{OAc})_{2}$ to $\mathrm{CuOAc}$ is significant because it enables the deposition of $\mathrm{Cu}(\mathrm{I})$ films from a $\mathrm{Cu}(\mathrm{II})$ precursor without the need for a reducing agent.

To examine the use of $\mathrm{Cu}(\mathrm{OAc})_{2}$ as a precursor in ALD, we have conducted a complete process development study using water vapor as the co-reactant. This precursor combination produces $\mathrm{Cu}_{2} \mathrm{O}$ films at deposition temperatures of $180-220$ ${ }^{\circ} \mathrm{C}$. The deposition chemistry described herein fulfills the characteristics of an exemplary ALD process, namely saturation with respect to both precursors, accurate thickness control, and the deposition of highly crystalline, impurity-free films. Moreover, we demonstrate that this ALD chemistry can be used to fabricate photoconductor devices and that these devices exhibit photoconductivity and appreciable spectral responsivity under illumination in the visible wavelength range.

\section{RESULTS AND DISCUSSION}

Film Deposition Experiments. In the film deposition experiments, both $\mathrm{Cu}(\mathrm{OAc})_{2} \cdot \mathrm{H}_{2} \mathrm{O}$ and $\mathrm{Cu}(\mathrm{OAc})_{2}$ were tested for their suitability in ALD. No significant differences in the films deposited from $\mathrm{Cu}(\mathrm{OAc})_{2} \cdot \mathrm{H}_{2} \mathrm{O}$ compared to the films deposited from anhydrous $\mathrm{Cu}(\mathrm{OAc})_{2}$ were observed. An apparent reason for this finding is that $\mathrm{Cu}(\mathrm{OAc})_{2} \cdot \mathrm{H}_{2} \mathrm{O}$ is converted to anhydrous $\mathrm{Cu}(\mathrm{OAc})_{2}$ in the process of heating the copper precursor to its ALD source temperature, 175-185 ${ }^{\circ} \mathrm{C}$. Close to the source temperature, the reduction of $\mathrm{Cu}(\mathrm{OAc})_{2}$ starts to take place, and $\mathrm{CuOAc}$ is evaporated. Because several thermal events occur before the source temperature is reached, $\mathrm{Cu}(\mathrm{OAc})_{2} \cdot \mathrm{H}_{2} \mathrm{O}$ does not appear as an ideal ALD precursor. However, no adverse effects related to the conversion of $\mathrm{Cu}(\mathrm{OAc})_{2} \cdot \mathrm{H}_{2} \mathrm{O}$ to $\mathrm{Cu}(\mathrm{OAc})_{2}$ were detected in the film deposition experiments. Moreover, film deposition did not occur without the co-reactant $\left(\mathrm{H}_{2} \mathrm{O}\right)$, i.e., when the pulsing sequence $\left[\mathrm{Cu}(\mathrm{OAc})_{2} \cdot \mathrm{H}_{2} \mathrm{O}\right.$ - purge] was repeated for 

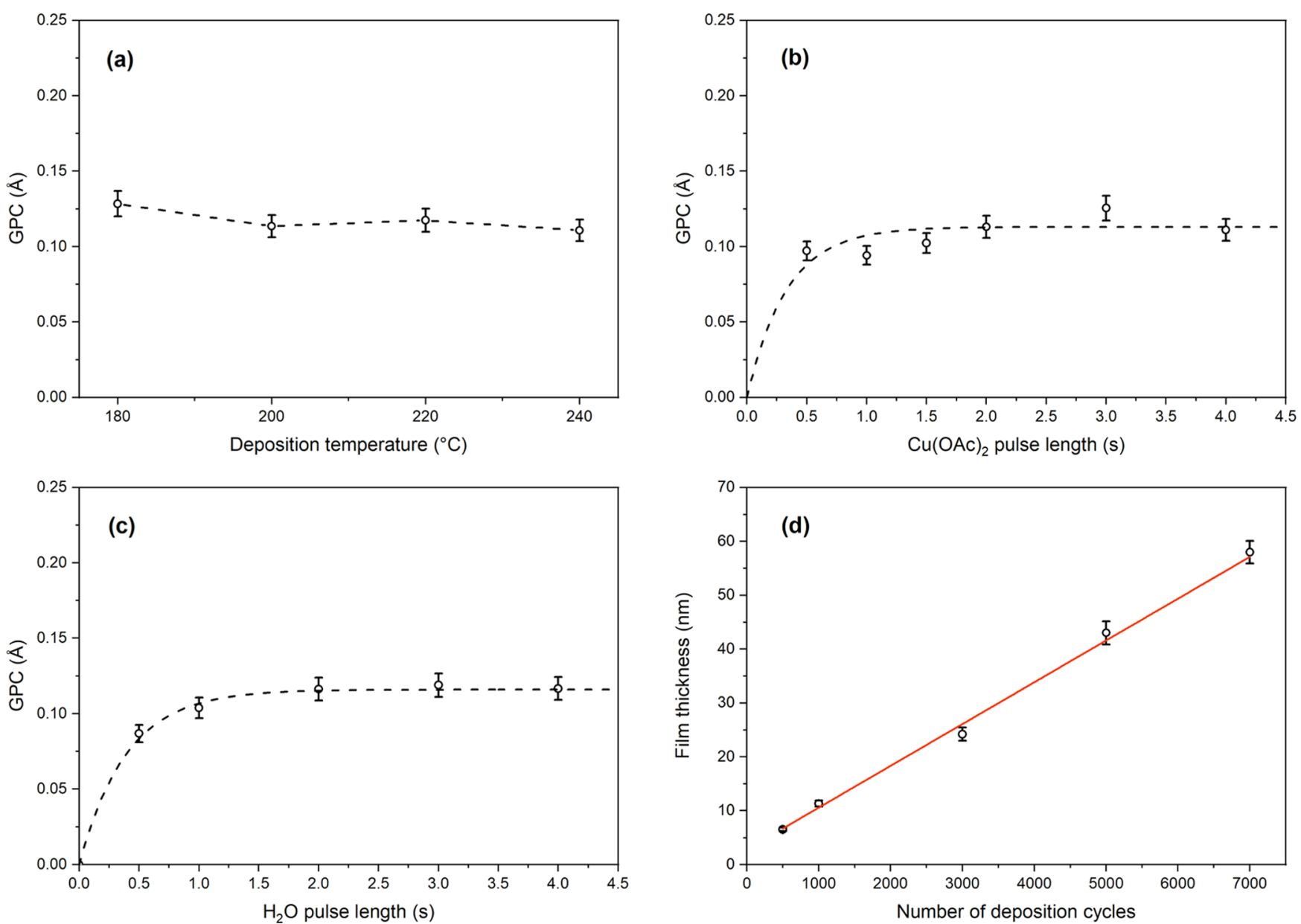

Figure 1. Growth characteristics of $\mathrm{Cu}_{2} \mathrm{O}$ films deposited from $\mathrm{Cu}(\mathrm{OAc})_{2}$ and $\mathrm{H}_{2} \mathrm{O}$. (a) GPC at deposition temperatures of 180, 200, 220, and 240 ${ }^{\circ} \mathrm{C}$, (b) the effect of $\mathrm{Cu}(\mathrm{OAc})_{2}$ pulse length, (c) the effect of $\mathrm{H}_{2} \mathrm{O}$ pulse length, (d) film thickness vs the number of deposition cycles at $200{ }^{\circ} \mathrm{C}$. The dashed lines in panels (a)-(c) are to guide the reader's eye. The solid line in panel (d) is a linear fit to the data points. The $R^{2}$ value describing the goodness of fit is 0.99365 .

2000 cycles, which indicates that the water of crystallization does not contribute to the film deposition. In the following discussion, we will refer to the copper precursor as $\mathrm{Cu}(\mathrm{OAc})_{2}$ because the water of crystallization in $\mathrm{Cu}(\mathrm{OAc})_{2} \cdot \mathrm{H}_{2} \mathrm{O}$ is removed at temperatures relevant to film deposition. Similarly, as the evaporating copper species is $\mathrm{Cu}(\mathrm{I})$ acetate, we refer to the copper precursor in the gas phase as CuOAc.

Film deposition was studied in the temperature range of 180-240 ${ }^{\circ} \mathrm{C}$. Deposition experiments related to the effect of deposition temperature and saturation were performed using 1000 deposition cycles. For the depositions done at $180^{\circ} \mathrm{C}$, a source temperature of $175{ }^{\circ} \mathrm{C}$ for $\mathrm{Cu}(\mathrm{OAc})_{2}$ was used to maintain a thermal gradient between the copper precursor and the substrates. For the film deposition experiments at 200-240 ${ }^{\circ} \mathrm{C}$, a source temperature of $185{ }^{\circ} \mathrm{C}$ was used. As seen from Figure 1a, the growth per cycle (GPC) values for films deposited by 1000 cycles were $0.13 \pm 0.01$ at $180{ }^{\circ} \mathrm{C}$ and 0.11 \pm 0.01 at $200-240{ }^{\circ} \mathrm{C}$.

The GPC values obtained for $\mathrm{Cu}_{2} \mathrm{O}$ in the temperature range of $180-220^{\circ} \mathrm{C}$ are low, which renders the deposition of films thicker than $100 \mathrm{~nm}$ impractical. However, we note that the GPC values obtained for the $\mathrm{Cu}_{2} \mathrm{O}$ deposition process described herein are comparable to those based on $\left({ }^{n} \mathrm{Bu}_{3} \mathrm{P}\right)_{2} \mathrm{Cu}(\mathrm{acac})+\mathrm{H}_{2} \mathrm{O}\left(<0.10 \AA\right.$ on $\mathrm{SiO}_{2}$ substrates $),{ }^{36}$ $\mathrm{Cu}(\mathrm{dmamb})_{2}+\mathrm{H}_{2} \mathrm{O}\left(0.13 \AA\right.$ at $\left.140-160{ }^{\circ} \mathrm{C}\right),{ }^{37}$ and
$\mathrm{Cu}(\mathrm{dmap})_{2}+\mathrm{H}_{2} \mathrm{O}$ processes $\left(0.12 \AA\right.$ at $\left.120-160{ }^{\circ} \mathrm{C}\right) .{ }^{39}$ Films deposited at $240{ }^{\circ} \mathrm{C}$ were visibly metallic due to the thermal decomposition of CuOAc. As the aim of this work was to deposit $\mathrm{Cu}_{2} \mathrm{O}$ films, deposition experiments at temperatures above $240{ }^{\circ} \mathrm{C}$ were not conducted.

Saturation experiments were performed with 1000 deposition cycles at $200{ }^{\circ} \mathrm{C}$. As seen from Figure $1 \mathrm{~b}, \mathrm{c}$, the saturative growth mode characteristic to ALD was obtained for both $\mathrm{Cu}(\mathrm{OAc})_{2}$ and $\mathrm{H}_{2} \mathrm{O}$ using 2.0 s pulses. For films deposited by 1000 cycles, $3.0 \mathrm{~s}$ long purge times for both precursors were sufficient for obtaining uniform films over $5 \times 5 \mathrm{~cm}^{2}$ substrates (Figure S1). Finally, the thicknesses of $\mathrm{Cu}_{2} \mathrm{O}$ films deposited at $200{ }^{\circ} \mathrm{C}$ with an increasing number of deposition cycles were measured (Figure 1d). Atypically, for an ALD metal oxide process, the GPC of the $\mathrm{Cu}_{2} \mathrm{O}$ films did not remain constant as the number of deposition cycles was increased. The application of 500 and 1000 deposition cycles at $200{ }^{\circ} \mathrm{C}$ resulted in films with thicknesses of 6.5 and $11.3 \mathrm{~nm}$, respectively, which averages to a GPC of $0.12 \AA$. With 3000,5000 , and 7000, the thicknesses of the obtained films were $24.2,43.0$, and $58.0 \mathrm{~nm}$, respectively, which averages to a GPC of $0.08 \AA$. This finding entails that the deposition of $\mathrm{Cu}_{2} \mathrm{O}$ using this process is substrate-enhanced in the early stages of film growth. ${ }^{54,55} \mathrm{~A}$ probable reason for this behavior is that the adsorption density of the copper precursor is higher on the native oxide- 

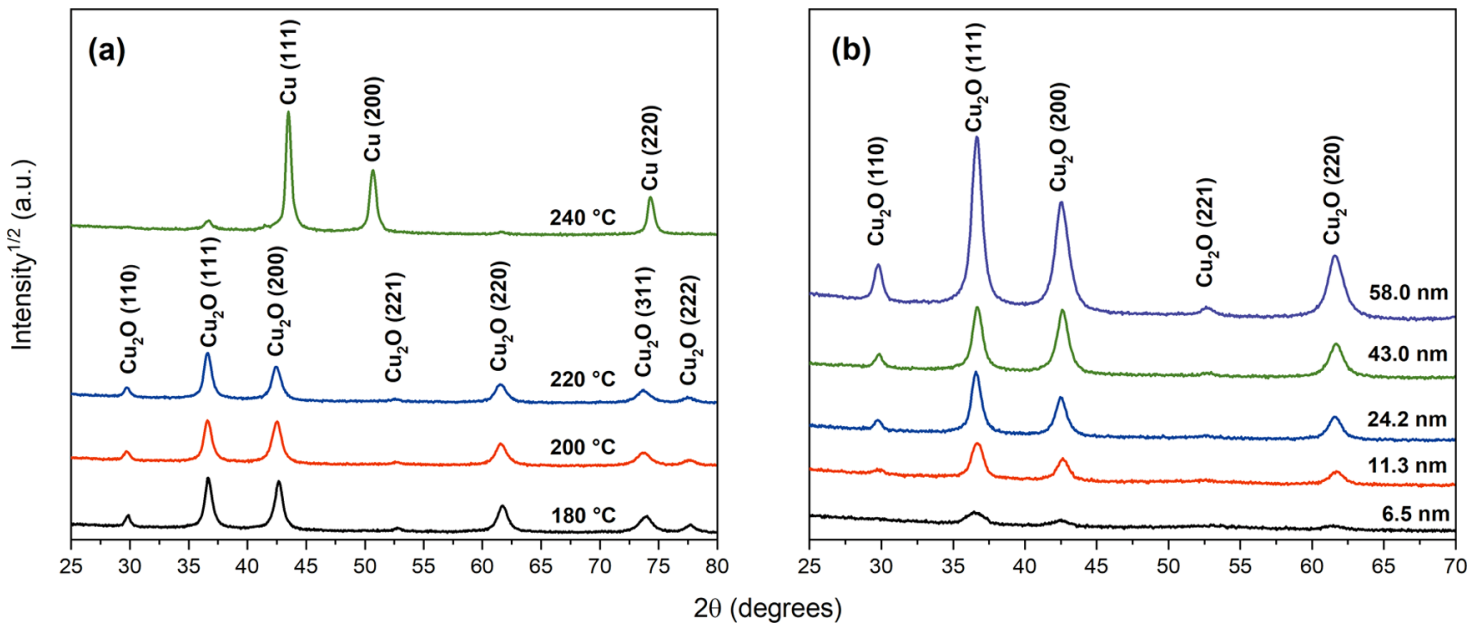

Figure 2. GI-XRD diffractograms of (a) $\mathrm{Cu}_{2} \mathrm{O}$ films deposited with 5000 cycles at $180-240{ }^{\circ} \mathrm{C}$ and (b) the effect of film thickness on crystallinity at a deposition temperature of $200^{\circ} \mathrm{C}$.

terminated $\mathrm{Si}$ than on the $\mathrm{Cu}_{2} \mathrm{O}$ film itself. We hypothesize that this is due to the lability of hydroxyl groups on $\mathrm{Cu}_{2} \mathrm{O}$ surfaces, as $\mathrm{Cu}(\mathrm{I})$ hydroxides are known to decompose to oxoterminated $\mathrm{Cu}_{2} \mathrm{O}$ at elevated temperatures. ${ }^{56}$

According to field emission scanning electron microscopy (FESEM) and atomic force microscopy (AFM) analyses (as discussed later), films deposited with 500 cycles on $\mathrm{Si}$ substrates are not continuous. Consequently, the effective surface area and the number of adsorption sites at the early stages of the film growth is higher compared to the stage where a $\mathrm{Cu}_{2} \mathrm{O}$ film fully covering the underlying $\mathrm{Si}$ substrate has formed. Despite the nonconstant GPC over an increasing number of deposition cycles, the thickness of $\mathrm{Cu}_{2} \mathrm{O}$ films deposited at $200{ }^{\circ} \mathrm{C}$ could be accurately controlled in the range of 5-60 nm, which signifies that the ALD chemistry described herein is a viable candidate to be used for applications in which sub-100 nm films are required. The good thickness control of this ALD process was also proven by depositing an approximately $50 \mathrm{~nm}$ thick $\mathrm{Cu}_{2} \mathrm{O}$ film on a trench structure with an aspect ratio of approximately $2: 1$. For this trench structure, $100 \%$ conformality was achieved using a pulse and purge sequence of $2 \mathrm{~s} \mathrm{Cu}(\mathrm{OAc})_{2}$ pulse $-7 \mathrm{~s}$ purge $-3 \mathrm{~s} \mathrm{H}_{2} \mathrm{O}$ pulse-7 s purge (Figure S2).

Film Crystallinity and Structure. The crystallinity of the films was studied with X-ray diffraction in the grazing incidence geometry. Grazing incidence X-ray diffraction (GIXRD) patterns of films deposited with 5000 cycles at 180-240 ${ }^{\circ} \mathrm{C}$ are shown in Figure 2a and the effect of the film thickness on the crystallinity of films deposited at $200{ }^{\circ} \mathrm{C}$ is shown in Figure $2 \mathrm{~b}$.

The peaks in the diffractograms shown in Figure 2 are indexed according to the ICCD cards for cubic $\mathrm{Cu}_{2} \mathrm{O}$ (ICCD PDF 5-667) and cubic $\mathrm{Cu}$ (ICCD PDF 4-836). According to GI-XRD analysis, the films deposited at $180-220{ }^{\circ} \mathrm{C}$ are polycrystalline, phase-pure cubic $\mathrm{Cu}_{2} \mathrm{O}$. The most intense reflections are those assignable to the (111) and (200) planes of cubic $\mathrm{Cu}_{2} \mathrm{O}$. Based on Rietveld refinement, ${ }^{57}$ the unit cell dimensions in $\mathrm{Cu}_{2} \mathrm{O}$ films deposited at $180-220{ }^{\circ} \mathrm{C}$ are within $\pm 0.01 \AA$ of the reported literature value of $4.2685 \AA .^{58}$ As discussed above, films deposited at $240{ }^{\circ} \mathrm{C}$ were visually metallic due to the thermal decomposition of the copper precursor. The GI-XRD pattern of films deposited at $240{ }^{\circ} \mathrm{C}$ confirmed the formation of metallic copper (Figure 2a).
However, these films were not pure metallic copper, as reflections assignable to both metallic $\mathrm{Cu}$ and $\mathrm{Cu}_{2} \mathrm{O}$ could be observed in the diffractogram. The adhesion of the films deposited at $240{ }^{\circ} \mathrm{C}$ was poor, which signifies that this ALD chemistry is not suitable for depositing metallic copper thin films on oxide surfaces. The saturation studies and GI-XRD experiments indicated that the optimal deposition temperature for this ALD process is $200{ }^{\circ} \mathrm{C}$. Therefore, this temperature was used to deposit films for further characterization, including morphology studies, compositional analysis, and study of optoelectronic properties.

The morphology of the $\mathrm{Cu}_{2} \mathrm{O}$ films was analyzed using FESEM and AFM. Plane-view micrographs of $\mathrm{Cu}_{2} \mathrm{O}$ film deposited on Si substrates with 500, 1000, 3000, 5000, and 7000 cycles are presented in Figure 3. As observed from Figure

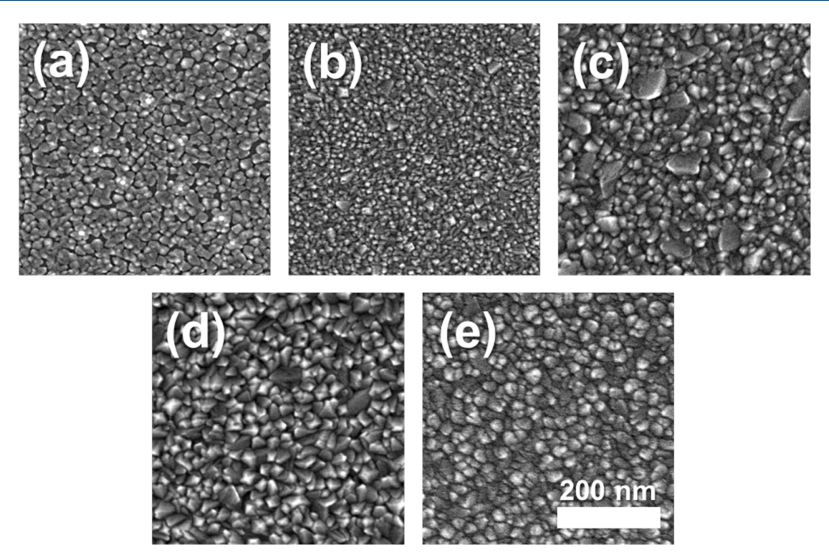

Figure 3. Representative plane-view FESEM micrographs of $\mathrm{Cu}_{2} \mathrm{O}$ films deposited at $200{ }^{\circ} \mathrm{C}$ over a cycle number of (a) $500(6.5 \mathrm{~nm})$, (b) $1000(11.3 \mathrm{~nm}),($ c) $3000(24.2 \mathrm{~nm})$, (d) $5000(43.0 \mathrm{~nm})$ and (e) $7000(58.0 \mathrm{~nm})$. The $200 \mathrm{~nm}$ scale bar applies to all images.

3a, films deposited over 500 cycles on $\mathrm{Si}$ are not continuous. Upon increasing the deposition cycle count to 1000, the underlying $\mathrm{Si}$ substrate is no longer observed, which indicates the formation of a continuous $\mathrm{Cu}_{2} \mathrm{O}$ film (Figure $3 \mathrm{~b}$ ). Films deposited with 1000, 3000, and 5000 cycles contained larger grains that emerge from the underlying polycrystalline layer. For films deposited over 7000 cycles, the larger grains were no 
longer observed, and a more uniform surface morphology was obtained.

The surface roughness of the $\mathrm{Cu}_{2} \mathrm{O}$ films was quantified using AFM. The average root-mean-square roughness $\left(R_{\mathrm{q}}\right)$ values of $\mathrm{Cu}_{2} \mathrm{O}$ films deposited with $500,1000,3000,5000$, and 7000 cycles are listed in Table 1 . Top-down view of AFM

Table 1. Root-Mean-Square Surface Roughness $\left(R_{\mathrm{q}}\right)$ Values of $\mathrm{Cu}_{2} \mathrm{O}$ Films Deposited at $200{ }^{\circ} \mathrm{C}$

$\begin{array}{llllll}\text { cycle count } & 500 & 1000 & 3000 & 5000 & 7000 \\ \text { film thickness }(\mathrm{nm}) & 6.5 & 11.3 & 24.2 & 43.0 & 58.0 \\ R_{\mathrm{q}}(\mathrm{nm}) & 4.0 & 1.9 & 3.4 & 7.7 & 9.3\end{array}$

images of these films is presented in Figure S3. According to the AFM results, the surface roughness of $\mathrm{Cu}_{2} \mathrm{O}$ films deposited at $200{ }^{\circ} \mathrm{C}$ increases with the increasing film thickness. This effect is common for polycrystalline ALD films and can be attributed to a film growth mechanism where the grain size grows with increasing film thickness. ${ }^{55}$

In comparison to other $\mathrm{ALD} \mathrm{Cu}_{2} \mathrm{O}$ processes, the deposition process presented herein produces films of similar surface roughness. For the $\mathrm{Cu}(\mathrm{dmamb})_{2}+\mathrm{H}_{2} \mathrm{O}$ process, $R_{\mathrm{q}}$ values of 4.8 and $6.1 \mathrm{~nm}$ were reported for $30 \mathrm{~nm}$ thick $\mathrm{Cu}_{2} \mathrm{O}$ films obtained at 180 and $240{ }^{\circ} \mathrm{C}$, respectively. ${ }^{37}$ These values are comparable to the root-mean-square roughness of $3.4 \mathrm{~nm}$ measured for a $24 \mathrm{~nm}$ thick $\mathrm{Cu}_{2} \mathrm{O}$ film deposited at $200{ }^{\circ} \mathrm{C}$. Notably, the surface roughness of the film deposited by 500 cycles is $4.0 \mathrm{~nm}$, which corresponds to approximately $60 \%$ of the nominal thickness of this film. Since 500 deposition cycles at $200{ }^{\circ} \mathrm{C}$ produces isolated islands instead of continuous films, high surface roughness is to be expected.

To study the early stage growth in more detail, the surface roughness of films deposited with 200, 400, 600, and 800 cycles was mapped. From the AFM images presented in Figure 4 , it can be observed that the film deposited with 200 cycles consists primarily of isolated copper oxide islands on the $\mathrm{Si}$ substrate surface, whereas 400 and 600 deposition cycles lead to the formation of a surface texture consisting of larger grains, and subsequently, to increased surface roughness $(3.6 \mathrm{~nm}$ for
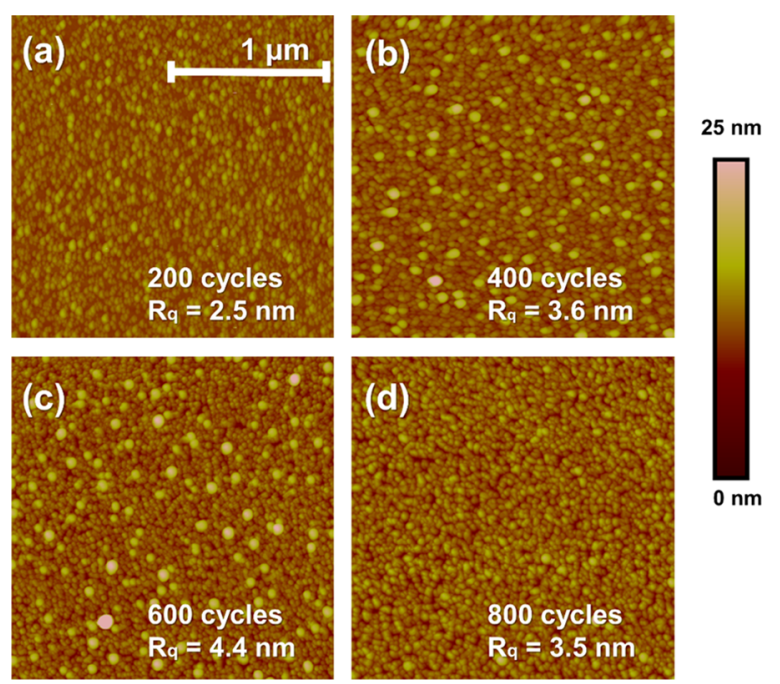

Figure 4. Top-down view of AFM images of $\mathrm{Cu}_{2} \mathrm{O}$ films deposited over (a) 200, (b) 400, (c) 600, and (d) 800 cycles at $200{ }^{\circ} \mathrm{C}$. The 1 $\mu \mathrm{m}$ scale bar and the $25 \mathrm{~nm}$ height scale apply to all images.
400 cycles and $4.4 \mathrm{~nm}$ for 600 cycles). After 800 deposition cycles, the film surface starts to smoothen, as evidenced by a decrease of $R_{\mathrm{q}}$ to $3.5 \mathrm{~nm}$. In comparison to a film deposited over 1000 cycles (film thickness $11 \mathrm{~nm}, R_{\mathrm{q}}=1.9 \mathrm{~nm}$ ), the sample deposited with 800 cycles has a higher surface roughness, which implies that at $200{ }^{\circ} \mathrm{C}$ continuous $\mathrm{Cu}_{2} \mathrm{O}$ layers are formed at a film thickness of approximately $11 \mathrm{~nm}$. We base this conclusion in the observation that a minimum in surface roughness is observed at 1000 deposition cycles (Figure S4).

Compositional Analysis of the Films. The composition of a $\mathrm{Cu}_{2} \mathrm{O}$ film deposited at $200{ }^{\circ} \mathrm{C}$ with 7000 cycles was studied using the combination of time-of-flight elastic recoil detection analysis (ToF-ERDA) and XPS. ToF-ERDA is an ion-beam technique that can be used to quantitatively detect all elements and that can be also used for depth profiling with a resolution in the order of nanometers, which makes this method useful in compositional analysis of thin films. ${ }^{59}$ According to ToF-ERDA measurements, the $\mathrm{Cu} / \mathrm{O}$ ratio in the analyzed film was 1.96, which signifies that the films are nearly stoichiometric $\mathrm{Cu}_{2} \mathrm{O}$ (Table 2).

Table 2. Elemental Composition (atomic \%) of a $\mathrm{Cu}_{2} \mathrm{O}$ Film Deposited over 7000 Cycles at $200{ }^{\circ} \mathrm{C}$ as Determined Using ToF-ERDA

\begin{tabular}{ccccc}
$\mathrm{Cu}$ & $\mathrm{O}$ & $\mathrm{H}$ & $\mathrm{C}$ & $\mathrm{Cu} / \mathrm{O}$ ratio \\
65.8 & 33.6 & 0.4 & $\leq 0.2$ & 1.96 \\
\hline
\end{tabular}

The composition of the films differs from the stoichiometric value of 2.0 , as the films were also found to contain minor amounts of light impurity elements, 0.4 atom $\%$ of hydrogen, and $\leq 0.2$ atom $\%$ of carbon. According to the ToF-ERDA depth profile presented in Figure 5a, the hydrogen in the films is concentrated on the surface, while the bulk of the films is free of impurities. This suggests that the surface impurities are hydroxides that form upon exposure to ambient moisture.

We emphasize that the amount of hydrogen and carbon impurities observed in the $\mathrm{Cu}_{2} \mathrm{O}$ films is exceptionally low for ALD metal oxide films. The low level of hydrogen and carbon impurities incorporated in the films indicates that the filmforming surface reactions between $\mathrm{CuOAc}$ and water vapor proceed in a clean manner without ligand decomposition. This is to be expected, as the most probable film-forming mechanism in ALD of metal oxides when using water vapor as the co-reactant is ligand exchange. ${ }^{60}$ In the case of a metal acetate precursor such as $\mathrm{CuOAc}$, the by-product of a ligand exchange reaction is acetic acid, which has a high vapor pressure and is thus unlikely to remain on the film surface. ${ }^{61}$ The existence of the ligand exchange mechanism is supported by an in situ reaction mechanism study performed by employing quadrupole mass spectrometer (QMS) and quartz crystal microbalance (QCM) techniques (Figure S5). The Supporting Information also contains further discussion on the question of the reaction mechanism.

To complement the ToF-ERDA experiments, the $\mathrm{Cu}_{2} \mathrm{O}$ films were analyzed with respect to the oxidation states of copper and oxygen using XPS. Peak fitting of the photoelectron spectra was performed using the parameters published by Biesinger et al. ${ }^{62,63}$ The XPS survey spectrum and a spectrum covering the entire $\mathrm{Cu} 2 \mathrm{p}$ binding energy region are shown in Figure S6. The most intense peak in the $\mathrm{Cu} 2 \mathrm{p}_{3 / 2}$ binding energy region was found at $932.4 \mathrm{eV}$, which lies $0.2 \mathrm{eV}$ 

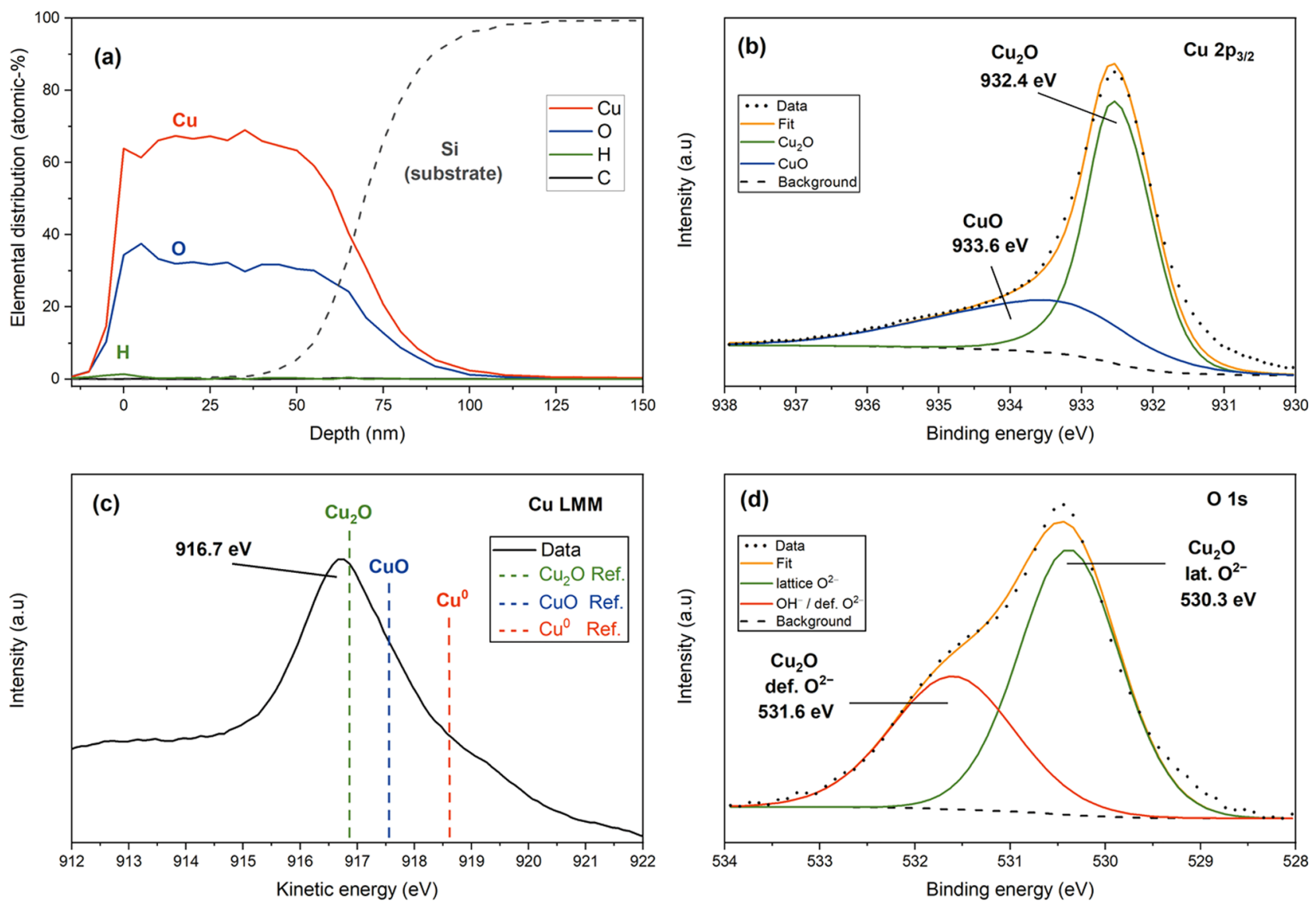

Figure 5. ToF-ERDA and XPS analysis of $\mathrm{Cu}_{2} \mathrm{O}$ films deposited at $200{ }^{\circ} \mathrm{C}$. (a) ToF-ERDA depth profile, (b) high-resolution photoelectron spectrum of the $\mathrm{Cu} 2 \mathrm{p}_{3 / 2}$ binding energy region, (c) Auger electron spectrum in the $\mathrm{Cu}$ LMM KE region, (d) high-resolution photoelectron spectrum of the $\mathrm{O} 1 \mathrm{~s}$ binding energy region.

(a)
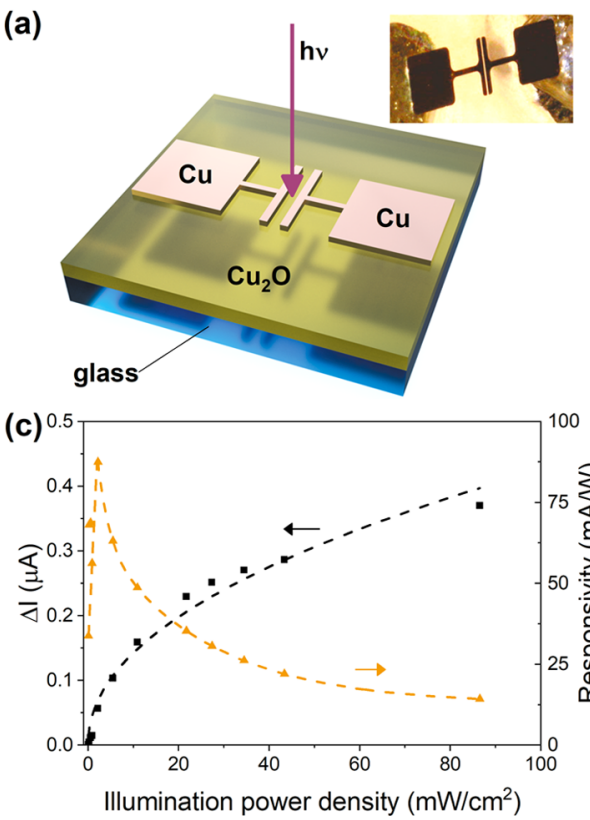
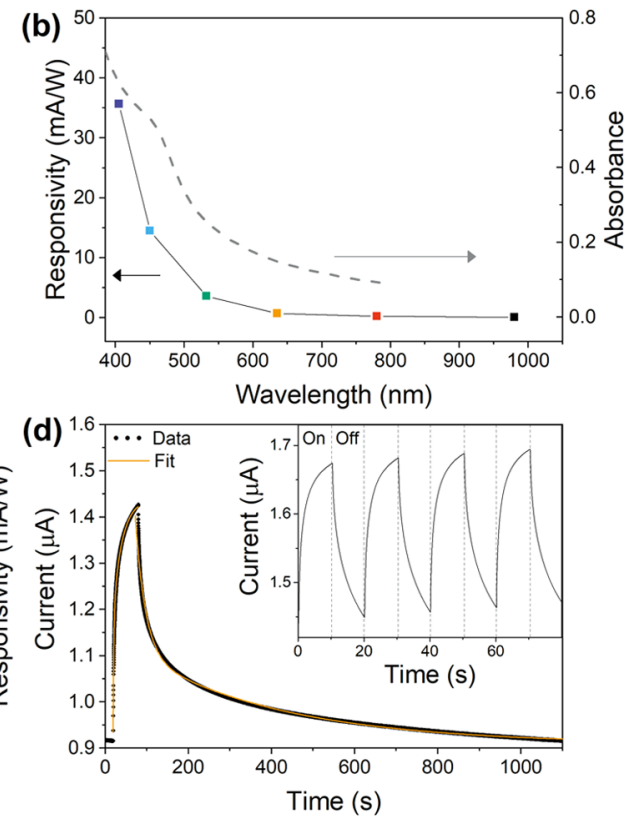

Figure 6. (a) Schematic presentation of the photoconductor test structure. Inset: digital optical microscopy image of the photoconductor structure from the glass side. (b) Photoconductor responsivity as a function of illumination wavelength and an absorbance spectrum of a $\mathrm{Cu}_{2} \mathrm{O}$ film deposited by 3000 cycles at $200{ }^{\circ} \mathrm{C}$. (c) Dependence of photocurrent and responsivity on light power density. (d) Time-dependent photocurrent response of the photoconductor illuminated for $1 \mathrm{~min}$. Inset: time-dependent photoresponse with chopped illumination (10 s on, $10 \mathrm{~s}$ off). In (b) (d) the photoconductor was under a $10 \mathrm{~V}$ bias. In (c) and (d) a $405 \mathrm{~nm}$ laser was used for illumination. 
higher than the reported literature value for $\mathrm{Cu}_{2} \mathrm{O}, 932.2 \mathrm{eV}$ (Figure 5c). ${ }^{63}$ Moreover, the main peak for $\mathrm{Cu} 2 \mathrm{p}_{3 / 2}$ at 932.4 $\mathrm{eV}$ shows asymmetry toward higher binding energy values. We assign the minor peak shift and asymmetry to partial surface oxidation, i.e., the formation of a $\mathrm{Cu}^{2+}$ terminated surface. Accounting for the minor oxidation of the film surface, the best fit to the main $\mathrm{Cu} 2 \mathrm{p}_{3 / 2}$ peak was obtained by deconvolution to $\mathrm{Cu}_{2} \mathrm{O}$ (the major peak at $932.4 \mathrm{eV}$ ) and $\mathrm{CuO}$ (the broad peak at $933.6 \mathrm{eV})$. The partial oxidation of surfaces is a well-known phenomenon for several thin film materials, including $\mathrm{Cu}_{2} \mathrm{O} \cdot{ }^{64,65}$ However, it has been shown that the surface oxidation of nanocrystalline $\mathrm{Cu}_{2} \mathrm{O}$ in ambient conditions proceeds only to a minor extent, ${ }^{65-67}$ as can also be observed for the films deposited in this work.

Further evidence for the deposition of $\mathrm{Cu}_{2} \mathrm{O}$ films with minimal surface oxidation was obtained from the $\mathrm{Cu}$ LMM spectrum (Figure 5c), which showed an intense peak assignable to $\mathrm{Cu}_{2} \mathrm{O}$ at $916.7 \mathrm{eV}^{63}$ Compared to the $\mathrm{Cu} 2 \mathrm{p}$ binding energy region, the $\mathrm{Cu}$ LMM peak serves as a reliable fingerprint for identifying between metallic $\mathrm{Cu}$ and $\mathrm{Cu}_{2} \mathrm{O}$. Although the $\mathrm{Cu} 2 \mathrm{p}_{3 / 2}$ binding energy values of $\mathrm{Cu}$ and $\mathrm{Cu}_{2} \mathrm{O}$ are separated only by $0.4 \mathrm{eV}$, the literature values for LMM kinetic energy of $\mathrm{Cu}(918.6 \mathrm{eV})$ and $\mathrm{Cu}_{2} \mathrm{O}(917.0 \mathrm{eV})$ are separated by $1.6 \mathrm{eV}$ and are therefore more suitable for identification between the metal and oxide. ${ }^{63}$ Moreover, the Auger parameter, i.e., the sum of the $\mathrm{Cu} 2 \mathrm{p}_{3 / 2}$ main peak binding energy and the $\mathrm{Cu}$ LMM main peak kinetic energy is $1849.1 \mathrm{eV}$, which is in excellent agreement with the literature value of $\mathrm{Cu}_{2} \mathrm{O}(1849.2 \mathrm{eV}) .^{63}$

To complete XPS analysis, the $\mathrm{O} 1 \mathrm{~s}$ spectra were investigated (Figure 5d). Deconvolution of the asymmetric peak found in the $\mathrm{O}$ 1s binding energy range showed maxima at 530.3 and $531.6 \mathrm{eV}$. The peak at $530.3 \mathrm{eV}$ corresponds to the lattice oxide of $\mathrm{Cu}_{2} \mathrm{O}$, whereas the peak at $531.6 \mathrm{eV}$ can be ascribed to a defective oxygen component in $\mathrm{Cu}_{2} \mathrm{O}$, or to surface hydroxyl species. ${ }^{62,63}$ Both of these options are possible sources for the $\mathrm{O} 1 \mathrm{~s}$ signal present at $531.6 \mathrm{eV}$ since the films were found to be slightly understoichiometric and contain excess hydrogen on the film surface (Figure 5a).

Optical and Electrical Characterization. $\mathrm{Cu}_{2} \mathrm{O}$ thin films hold potential for optoelectronic applications that rely on visible light because $\mathrm{Cu}_{2} \mathrm{O}$ has a high absorption coefficient and an optical band gap in the visible range. ${ }^{4}$ To estimate the optical band gap of our $\mathrm{Cu}_{2} \mathrm{O}$ films, we employed the Tauc plot method. ${ }^{8,69}$ Furthermore, to show that ultra-thin ALD films can be used as photoconductors, we prepared simple test structures (Figure 6a) and characterized the devices with respect to responsivity and time constants.

Tauc plot analysis for a $\mathrm{Cu}_{2} \mathrm{O}$ film deposited with 3000 cycles at $200{ }^{\circ} \mathrm{C}$ revealed a direct forbidden optical band gap of approximately $2.1 \mathrm{eV}$ (Figure S7), which is in agreement with values reported for $\mathrm{Cu}_{2} \mathrm{O}$ thin film samples. ${ }^{4}$ Characterization of the photoconductor structures showed that the spectral responsivity of the devices follows the optical absorbance of the $\mathrm{Cu}_{2} \mathrm{O}$ films (Figure $6 \mathrm{~b}$ ) and that the responsivity increases with increasing photon energy when the incident illumination power density is kept constant. Further photocurrent measurements revealed a definite dependence between responsivity and the illumination power density (Figure $6 \mathrm{c}$ ). Fitting a power law function $\Delta I=a P^{b}$, where $\Delta I$ is the photocurrent, $P$ is the incident illumination power density, and $a$ and $b$ are constants yields $\Delta I \approx P^{0.5}$. As evident from Figure $6 \mathrm{c}$ and the fitted power law exponent, the dependence of responsivity on illumination power density is nonlinear, which is typical for photoconductor structures. The highest responsivity, approximately $90 \mathrm{~mA} / \mathrm{W}$, was observed when using $405 \mathrm{~nm}$ illumination at an incident power density of $1 \mathrm{~mW} / \mathrm{cm}^{2}$. The responsivity of our devices based on $24 \mathrm{~nm}$ thick $\mathrm{Cu}_{2} \mathrm{O}$ films is comparable to values reported for photodetectors based on electrodeposited, approximately $1 \mu \mathrm{m}$ thick $\mathrm{Cu}_{2} \mathrm{O}$ films. ${ }^{70}$

In photodetection, time constants for the response $\left(\tau_{\mathrm{r}}\right)$ and decay $\left(\tau_{\mathrm{d}}\right)$ are of interest. While our proof-of-concept photoconductor devices displayed promising responsivities, temporal photocurrent measurements revealed slow switching characteristics (Figure 6d). The photocurrent did not saturate even after $1 \mathrm{~min}$ of illumination and the time needed for recovery was correspondingly long, in the order of $5 \mathrm{~min}$. The response and decay processes can be represented by a biexponential model incorporating fast $\left(\tau_{\mathrm{r} 1}, \tau_{\mathrm{d} 1}\right)$ and slow $\left(\tau_{\mathrm{r} 2}, \tau_{\mathrm{d} 2}\right)$ components. From biexponential curve fits shown in Figure $6 \mathrm{~d}$, we obtain time constants of $\tau_{\mathrm{r} 1}=2 \mathrm{~s}, \tau_{\mathrm{d} 1}=22 \mathrm{~s}, \tau_{\mathrm{r} 2}=$ $24 \mathrm{~s}$, and $\tau_{\mathrm{d} 2}=352 \mathrm{~s}$. We propose that the slow switching behavior originates from the persistent photoconductivity (PPC) effect intrinsic to $\mathrm{Cu}_{2} \mathrm{O}$. Two models have been proposed to explain the PPC effect in $\mathrm{Cu}_{2} \mathrm{O}$, that is, a model based on dissociation and association of copper vacancy complexes by Kuzêl, ${ }^{71}$ and an electron trapping model by Tapiero et al. ${ }^{72}$ The PPC effect causes the conductivity of $\mathrm{Cu}_{2} \mathrm{O}$ to increase slowly under illumination and the increased conductivity to persist even when the illumination is stopped. For photoconductor devices, this implies an increase in the baseline current under illumination (Figure $6 \mathrm{~d}$ inset). In bulk crystals of $\mathrm{Cu}_{2} \mathrm{O}$, the increase in conductivity after illumination can persist for several days. ${ }^{73}$ However, in the case of our ultrathin photoconductors, the nanometer level thickness of the device contributes to a significantly faster PPC discharge. The PPC effect in $\mathrm{Cu}_{2} \mathrm{O}$ can also be discharged by heating the material to $120{ }^{\circ} \mathrm{C}$ and above, ${ }^{73}$ however, such an approach is impractical for photodetection. Alternatively, introduction of dopants to the $\mathrm{Cu}_{2} \mathrm{O}$ lattice can be used to suppress the PPC effect. Isseroff et al. suggested that lithium doping can suppress $\mathrm{PPC}$ in $\mathrm{Cu}_{2} \mathrm{O},{ }^{74}$ which in turn could enable photodetection at operating temperatures close to RT, and furthermore lead to improved response and decay times in photodetector devices based on $\mathrm{Cu}_{2} \mathrm{O}$. As ALD is known for its capability to produce doped transition metal oxide thin films of high-quality, ${ }^{43}$ we expect more detailed studies on this topic to emerge in the future.

\section{CONCLUSIONS}

In this work, we have studied the applicability of copper(II) acetate as a copper precursor in ALD. Deposition of highquality $\mathrm{Cu}_{2} \mathrm{O}$ thin films was achieved in the temperature range of $180-220^{\circ} \mathrm{C}$ when water vapor was used as the co-reactant. The ALD process described herein exhibits saturative growth characteristics, enables accurate thickness control, and can be used to deposit conformal films on trench structures (AR 2:1). GI-XRD, ToF-ERDA, and XPS measurements showed that the films deposited at $200{ }^{\circ} \mathrm{C}$ are polycrystalline, phase-pure, and nearly stoichiometric $\mathrm{Cu}_{2} \mathrm{O}$ with less than 0.5 atom \% hydrogen and carbon impurities. As the deposition temperature range of this ALD process matches well with processes reported for other transition metal oxides, the $\mathrm{Cu}(\mathrm{OAc})_{2}+$ $\mathrm{H}_{2} \mathrm{O}$ ALD process can enable new routes for depositing ternary and quaternary $\mathrm{Cu}^{+}$-based materials, such as $\mathrm{CuAlO}_{2}$ and $\mathrm{SrCu}_{2} \mathrm{O}_{2}$. Finally, as a proof-of-concept, we have 
demonstrated that ultra-thin $\mathrm{Cu}_{2} \mathrm{O}$ films made using ALD exhibit appreciable photoconductivity and photoresponsivity in the visible wavelength region. The use of $\mathrm{Cu}_{2} \mathrm{O}$ thin films for photodetection applications is, however, obstructed by the persistent photoconductivity phenomenon, which manifests as the slow response and decay times. According to our experiments, the adverse effect of persistent photoconductivity is less prominent in $\mathrm{Cu}_{2} \mathrm{O}$ thin films than in bulk crystals of $\mathrm{Cu}_{2} \mathrm{O}$. Further material engineering efforts, such as cation doping may improve the performance of $\mathrm{Cu}_{2} \mathrm{O}$-based devices and should thus be explored.

\section{MATERIALS AND METHODS}

Film Deposition. $\mathrm{Cu}_{2} \mathrm{O}$ thin films were deposited using a commercial, hot-wall F-120 ALD reactor operated in the crossflow configuration. ${ }^{75}$ Nitrogen (AGA, 99.999\%, $\mathrm{O}_{2} \leq 3 \mathrm{ppm}$, $\mathrm{H}_{2} \mathrm{O} \leq 3 \mathrm{ppm}$ ) was used as both carrier and purging gas at a flow rate of $400 \mathrm{sccm}$. The reactor pressure during the depositions was in the order of 10 mbar. Films were deposited on $5 \times 5 \mathrm{~cm}^{2}$ squares of soda lime glass (SLG) and native oxide-terminated $\mathrm{Si}(100)$ (Okmetic Oy, Vantaa, Finland). The SLG substrates were cleaned using ultrasonication with successive baths of an alkaline cleaning solution, absolute ethanol, and deionized water, whereas the Si substrates were used as received. Copper(II) acetate was evaporated from an open glass boat held inside the ALD reactor at either 175 or $185{ }^{\circ} \mathrm{C}$ depending on the deposition temperature. Both the monohydrate, $\mathrm{Cu}(\mathrm{OAc})_{2} \cdot \mathrm{H}_{2} \mathrm{O}$ (Sigma Aldrich, $\geq 99.0 \%$ ) and anhydrous $\mathrm{Cu}(\mathrm{OAc})_{2}$ (Sigma Aldrich, 99.99\%) were used in the deposition experiments. Water vapor was led to the reactor through a needle valve from an external reservoir held at room temperature.

Film Characterization. All characterization studies were performed using films deposited on $\mathrm{Si}(100)$ substrates unless otherwise noted. Film thickness was measured with X-ray reflectivity using a PANalytical X'Pert Pro MPD diffractometer equipped with an X-ray source emitting $\mathrm{Cu} \mathrm{K} \alpha$ radiation $(\lambda=$ $1.54 \AA$ ) . The same diffractometer was also used to perform $\mathrm{X}$ ray diffraction (XRD) experiments. The XRD measurements were performed in the grazing incidence (GI) geometry at an incidence angle of $1^{\circ}$.

Electron microscope images of the films were obtained using a Hitachi S4800 field emission scanning electron microscope (FESEM). Atomic force microscopy (AFM) experiments were performed using a Veeco Multimode $\mathrm{V}$ tool equipped with a Nanoscope V controller. The AFM images were captured in the intermittent contact mode (tapping mode) in air using $\mathrm{Si}$ probes with a maximum nominal radius of $10 \mathrm{~nm}$ (Bruker). To remove artefacts caused by sample tilt and scanner bow, the images were flattened using an algorithm included in the Nanoscope 1.6 software package (Bruker). Film roughness was calculated from $2 \times 2 \mu \mathrm{m}^{2}$ images as root-mean-square $\left(R_{\mathrm{q}}\right)$ values.

The film composition was studied using time-of-flight elastic recoil detection analysis (ToF-ERDA). The ToF-ERDA measurements were conducted using a $50 \mathrm{MeV}{ }^{127} \mathrm{I}^{9+}$ ion beam in a configuration described in full elsewhere. ${ }^{76}$ The chemical state of the films was studied using X-ray photoelectron spectroscopy (XPS). The XPS spectra were collected with an Omicron ARGUS spectrometer operated at a pass energy of $20 \mathrm{eV}$. The thin film samples were excited with Xrays emitted from a standard $\mathrm{Mg}$ source ( $\mathrm{K} \alpha$ line, photon energy of $1253.6 \mathrm{eV}$ ). No sputtering was performed prior to the measurements. The binding energy scale was calibrated using the $C$ 1s peak of ambient hydrocarbons located at 284.8 $\mathrm{eV}$. Peak fitting was performed using the CasaXPS software package (www.casaxps.com).

Absorbance spectra of $\mathrm{Cu}_{2} \mathrm{O}$ films deposited on SLG substrates were measured in the wavelength range of 200$800 \mathrm{~nm}$ using a Shimadzu UV-2600 spectrophotometer. Tauc plots constructed from the absorbance data were used to estimate the optical band gaps of the films. The band gap analysis was performed for a direct forbidden band gap, as prompted by Malerba et al. ${ }^{4}$

Photoconductor Fabrication and Electrical Measurements. Photoconductor structures were made by evaporating copper electrodes through a source-drain shadow mask (Ossila E321, channel width $1 \mathrm{~mm}$, channel length $30 \mu \mathrm{m}$ ) onto $\mathrm{Cu}_{2} \mathrm{O}$ films deposited on SLG substrates by 3000 cycles at $200{ }^{\circ} \mathrm{C}$ (film thickness of approximately $24 \mathrm{~nm}$ ). Electrical measurements were performed using a Keithley 2450 sourcemeter. Laser diodes emitting at 405, 450, 532, 635, 780 , and $980 \mathrm{~nm}$ (Thorlabs) were used to illuminate the devices from the film side. The incident power density on the device surface was controlled with neutral density filters. Due to the persistent photoconductivity effect in $\mathrm{Cu}_{2} \mathrm{O}$, responsivity values were calculated from the difference between the photocurrent and dark current obtained from temporal photocurrent measurements (sample illuminated for $10 \mathrm{~s}$ and kept in the dark for $10 \mathrm{~s}$ ).

\section{ASSOCIATED CONTENT}

\section{Supporting Information}

The Supporting Information is available free of charge on the ACS Publications website at DOI: 10.1021/acsomega.9b01351.

Uniformity analysis of $\mathrm{Cu}_{2} \mathrm{O}$ films deposited at $200{ }^{\circ} \mathrm{C}$ (Figure S1), cross-sectional FESEM image of a $\mathrm{Cu}_{2} \mathrm{O}$ film deposited on a patterned Si substrate (Figure S2), additional top-down AFM images and AFM analysis (Figures S3 and S4), results and discussion of the in situ reaction mechanism study performed using quadrupole mass spectroscopy (QMS) and quartz crystal microbalance (QCM) techniques (Figure S5), additional Xray photoelectron spectra (Figure S6), and Tauc plot and UV-Vis absorbance data of $\mathrm{Cu}_{2} \mathrm{O}$ films (Figure S7) (PDF)

\section{AUTHOR INFORMATION}

\section{Corresponding Author}

*E-mail: tomi.iivonen@helsinki.fi. ORCID $\odot$

Tomi Iivonen: 0000-0003-1000-5609

Georgi Popov: 0000-0003-1233-8327

Heta-Elisa Nieminen: 0000-0003-1361-3829

Marianna Kemell: 0000-0002-3583-2064

Miika Mattinen: 0000-0003-4837-1823

Mikko Ritala: 0000-0002-6210-2980

Markku Leskelä: 0000-0001-5830-2800

\section{Author Contributions}

This manuscript was written through contributions of all authors.

Notes

The authors declare no competing financial interest. 


\section{ACKNOWLEDGMENTS}

The first film depositions using $\mathrm{Cu}(\mathrm{OAc})_{2} \cdot \mathrm{H}_{2} \mathrm{O}$ and water vapor were performed by Dr. Antti Rahtu. The work leading to these results has been funded by the EU-FP7 Grant "4GPHOTOCAT" (Grant No. 309636) and by the Finnish Center of Excellence in Atomic Layer Deposition.

\section{REFERENCES}

(1) Werner, A.; Hochheimer, H. D. High-Pressure x-Ray Study of $\mathrm{Cu}_{2} \mathrm{O}$ and $\mathrm{Ag}_{2} \mathrm{O}$. Phys. Rev. B 1982, 25, 5929-5934.

(2) Paul, G. K.; Nawa, Y.; Sato, H.; Sakurai, T.; Akimoto, K. Defects in $\mathrm{Cu}_{2} \mathrm{O}$ Studied by Deep Level Transient Spectroscopy. Appl. Phys. Lett. 2006, 88, No. 141901.

(3) Nolan, M.; Elliott, S. D. The P-Type Conduction Mechanism in $\mathrm{Cu}_{2} \mathrm{O}$ : A First Principles Study. Phys. Chem. Chem. Phys. 2006, 8, 5350-5358.

(4) Malerba, C.; Biccari, F.; Leonor Azanza Ricardo, C.; D’Incau, M.; Scardi, P.; Mittiga, A. Absorption Coefficient of Bulk and Thin Film $\mathrm{Cu}_{2}$ O. Sol. Energy Mater. Sol. Cells 2011, 95, 2848-2854.

(5) Ghijsen, J.; Tjeng, L. H.; van Elp, J.; Eskes, H.; Westerink, J.; Sawatzky, G. A.; Czyzyk, M. T. Electronic Structure of $\mathrm{Cu}_{2} \mathrm{O}$ and CuO. Phys. Rev. B 1988, 38, 11322-11330.

(6) Brattain, W. H. The Copper Oxide Rectifier. Rev. Mod. Phys. 1951, 23, 203-212.

(7) Ishizuka, S.; Maruyama, T.; Akimoto, K. Thin-Film Deposition of $\mathrm{Cu}_{2} \mathrm{O}$ by Reactive Radio-Frequency Magnetron Sputtering. Jpn. J. Appl. Phys. 2000, 39, L786-L788.

(8) Matsumura, H.; Fuji, A.; Kitatani, T. Properties of High-Mobility $\mathrm{Cu}_{2} \mathrm{O}$ Films Prepared by Thermal Oxidation of $\mathrm{Cu}$ at Low Temperatures. Jpn. J. Appl. Phys. 1996, 35, 5631.

(9) Musa, A. O.; Akomolafe, T.; Carter, M. J. Production of Cuprous Oxide, a Solar Cell Material, by Thermal Oxidation and a Study of Its Physical and Electrical Properties. Sol. Energy Mater. Sol. Cells 1998, 51, 305-316.

(10) Matsuzaki, K.; Nomura, K.; Yanagi, H.; Kamiya, T.; Hirano, M.; Hosono, H. Epitaxial Growth of High Mobility $\mathrm{Cu}_{2} \mathrm{O}$ Thin Films and Application to p-Channel Thin Film Transistor. Appl. Phys. Lett. 2008, 93, No. 202107.

(11) Liao, L.; Yan, B.; Hao, Y. F.; Xing, G. Z.; Liu, J. P.; Zhao, B. C.; Shen, Z. X.; Wu, T.; Wang, L.; Thong, J. T. L.; et al. P-Type Electrical, Photoconductive, and Anomalous Ferromagnetic Properties of $\mathrm{Cu}_{2} \mathrm{O}$ Nanowires. Appl. Phys. Lett. 2009, 94, No. 113106.

(12) Minami, T.; Nishi, Y.; Miyata, T.; Nomoto, J. High-Efficiency Oxide Solar Cells with $\mathrm{ZnO} / \mathrm{Cu}_{2} \mathrm{O}$ Heterojunction Fabricated on Thermally Oxidized $\mathrm{Cu}_{2} \mathrm{O}$ Sheets. Appl. Phys. Express 2011, 4, No. 062301.

(13) Minami, T.; Nishi, Y.; Miyata, T. High-Efficiency $\mathrm{Cu}_{2} \mathrm{O}$-Based Heterojunction Solar Cells Fabricated Using a $\mathrm{Ga}_{2} \mathrm{O}_{3}$ Thin Film as nType Layer. Appl. Phys. Express 2013, 6, No. 044101.

(14) Hsu, Y.-K.; Wu, J.-R.; Chen, M.-H.; Chen, Y.-C.; Lin, Y.-G. Fabrication of Homojunction $\mathrm{Cu}_{2} \mathrm{O}$ Solar Cells by Electrochemical Deposition. Appl. Surf. Sci. 2015, 354, 8-13.

(15) Wijesundera, R. P.; Gunawardhana, L. K. A. D. D. S.; Siripala, W. Electrodeposited $\mathrm{Cu}_{2} \mathrm{O}$ Homojunction Solar Cells: Fabrication of a Cell of High Short Circuit Photocurrent. Sol. Energy Mater. Sol. Cells 2016, 157, 881-886.

(16) Paracchino, A.; Laporte, V.; Sivula, K.; Grätzel, M.; Thimsen, E. Highly Active Oxide Photocathode for Photoelectrochemical Water Reduction. Nat. Mater. 2011, 10, 456-461.

(17) Luo, J.; Steier, L.; Son, M.-K.; Schreier, M.; Mayer, M. T.; Grätzel, $\mathrm{M} . \mathrm{Cu}_{2} \mathrm{O}$ Nanowire Photocathodes for Efficient and Durable Solar Water Splitting. Nano Lett. 2016, 16, 1848-1857.

(18) Yao, Z. Q.; Liu, S. L.; Zhang, L.; He, B.; Kumar, A.; Jiang, X.; Zhang, W. J.; Shao, G. Room Temperature Fabrication of P-Channel $\mathrm{Cu}_{2} \mathrm{O}$ Thin-Film Transistors on Flexible Polyethylene Terephthalate Substrates. Appl. Phys. Lett. 2012, 101, No. 042114.
(19) Chen, A.; Haddad, S.; Wu, Y. C.; Lan, Z.; Fang, T. N.; Kaza, S. Switching Characteristics of $\mathrm{Cu}_{2} \mathrm{O}$ Metal-Insulator-Metal Resistive Memory. Appl. Phys. Lett. 2007, 91, No. 123517.

(20) Chen, A.; Haddad, S.; Wu, Y. C.; Fang, T. N.; Kaza, S.; Lan, Z. Erasing Characteristics of $\mathrm{Cu}_{2} \mathrm{O}$ Metal-Insulator-Metal Resistive Switching Memory. Appl. Phys. Lett. 2008, 92, No. 013503.

(21) Hsueh, H. T.; Chang, S. J.; Weng, W. Y.; Hsu, C. L.; Hsueh, T. J.; Hung, F. Y.; Wu, S. L.; Dai, B. T. Fabrication and Characterization of Coaxial P-Copper Oxide/n-ZnO Nanowire Photodiodes. IEEE Trans. Nanotechnol. 2012, 11, 127-133.

(22) Yang, Z.; Chiang, C.-K.; Chang, H.-T. Synthesis of Fluorescent and Photovoltaic $\mathrm{Cu}_{2} \mathrm{O}$ Nanocubes. Nanotechnology 2008, 19, No. 025604.

(23) Kim, H.; Kim, S.-H.; Ko, K. Y.; Kim, H.; Kim, J.; Oh, J.; Lee, H.-B.-R. High Efficiency N-Si/p-Cu2O Core-Shell Nanowires Photodiode Prepared by Atomic Layer Deposition of $\mathrm{Cu}_{2} \mathrm{O}$ on WellOrdered Si Nanowires Array. Electron. Mater. Lett. 2016, 12, 404410.

(24) Kawazoe, H.; Yasukawa, M.; Hyodo, H.; Kurita, M.; Yanagi, H.; Hosono, H. P-Type Electrical Conduction in Transparent Thin Films of $\mathrm{CuAlO}_{2}$. Nature 1997, 389, 939.

(25) Kudo, A.; Yanagi, H.; Hosono, H.; Kawazoe, H. $\mathrm{SrCu}_{2} \mathrm{O}_{2}$ : A pType Conductive Oxide with Wide Band Gap. Appl. Phys. Lett. 1998, $73,220-222$.

(26) Hosono, H. Recent Progress in Transparent Oxide Semiconductors: Materials and Device Application. Thin Solid Films 2007, $515,6000-6014$.

(27) Sullivan, I.; Zoellner, B.; Maggard, P. A. Copper(I)-Based pType Oxides for Photoelectrochemical and Photovoltaic Solar Energy Conversion. Chem. Mater. 2016, 28, 5999-6016.

(28) Luo, X.-L.; Wang, M.-J.; Yang, D.-S.; Yang, J.; Chen, Y.-S. Hydrothermal Synthesis of Morphology Controllable $\mathrm{Cu}_{2} \mathrm{O}$ and Their Catalysis in Thermal Decomposition of Ammonium Perchlorate. J. Ind. Eng. Chem. 2015, 32, 313-318.

(29) de Jongh, P. E.; Vanmaekelbergh, D.; Kelly, J. J. $\mathrm{Cu}_{2} \mathrm{O}$ : Electrodeposition and Characterization. Chem. Mater. 1999, 11, 3512-3517.

(30) Ray, S. C. Preparation of Copper Oxide Thin Film by the Solgel-like Dip Technique and Study of Their Structural and Optical Properties. Sol. Energy Mater. Sol. Cells 2001, 68, 307-312.

(31) Biccari, F.; Malerba, C.; Mittiga, A. Chlorine Doping of $\mathrm{Cu}_{2} \mathrm{O}$. Sol. Energy Mater. Sol. Cells 2010, 94, 1947-1952.

(32) Maruyama, T. Copper Oxide Thin Films Prepared by Chemical Vapor Deposition from Copper Dipivaloylmethanate. Sol. Energy Mater. Sol. Cells 1998, 56, 85-92.

(33) Kobayashi, H.; Nakamura, T.; Takahashi, N. Preparation of $\mathrm{Cu}_{2} \mathrm{O}$ Films on $\mathrm{MgO}$ (110) Substrate by Means of Halide Chemical Vapor Deposition under Atmospheric Pressure. Mater. Chem. Phys. 2007, 106, 292-295.

(34) Barreca, D.; Fornasiero, P.; Gasparotto, A.; Gombac, V.; Maccato, C.; Montini, T.; Tondello, E. The Potential of Supported $\mathrm{Cu}_{2} \mathrm{O}$ and $\mathrm{CuO}$ Nanosystems in Photocatalytic $\mathrm{H} 2$ Production. ChemSusChem 2009, 2, 230-233.

(35) Törndahl, T. Atomic Layer Deposition of Copper, Copper(I) Oxide and Copper(I) Nitride on Oxide Substrates. Ph.D. Thesis, University of Uppsala: Sweden, 2004.

(36) Waechtler, T.; Oswald, S.; Roth, N.; Jakob, A.; Lang, H.; Ecke, R.; Schulz, S. E.; Gessner, T.; Moskvinova, A.; Schulze, S.; et al. Copper Oxide Films Grown by Atomic Layer Deposition from Bis(Tri-n-Butylphosphane)Copper(I)Acetylacetonate on $\mathrm{Ta}, \mathrm{TaN}$, $\mathrm{Ru}$, and $\mathrm{SiO}_{2}$. J. Electrochem. Soc. 2009, 156, H453-H459.

(37) Kim, H.; Lee, M. Y.; Kim, S.-H.; Bae, S. I.; Ko, K. Y.; Kim, H.; Kwon, K.-W.; Hwang, J.-H.; Lee, D.-J. Highly-Conformal p-Type Copper(I) Oxide $\left(\mathrm{Cu}_{2} \mathrm{O}\right)$ Thin Films by Atomic Layer Deposition Using a Fluorine-Free Amino-Alkoxide Precursor. Appl. Surf. Sci. 2015, 349, 673-682.

(38) Lee, M. Y.; Kim, S.-H.; Park, I.-K. $\mathrm{Cu}_{2} \mathrm{O}$ Quantum Dots Emitting Visible Light Grown by Atomic Layer Deposition. Phys. B 2016, 500, 4-8. 
(39) Avila, J. R.; Peters, A. W.; Li, Z.; Ortuño, M. A.; Martinson, A. B. F.; Cramer, C. J.; Hupp, J. T.; Farha, O. K. Atomic Layer Deposition of $\mathrm{Cu}(\mathrm{I})$ Oxide Films Using $\mathrm{Cu}$ (II) Bis(Dimethylamino2-Propoxide) and Water. Dalton Trans. 2017, 46, 5790-5795.

(40) George, S. M. Atomic Layer Deposition: An Overview. Chem. Rev. 2010, 110, 111-131.

(41) Ritala, M.; Niinisto, J. Industrial Applications of Atomic Layer Deposition. ECS Trans. 2009, 25, 641-652.

(42) Leskelä, M.; Ritala, M. Atomic Layer Deposition (ALD): From Precursors to Thin Film Structures. Thin Solid Films 2002, 409, 138146.

(43) Mackus, A. J. M.; Schneider, J. R.; MacIsaac, C.; Baker, J. G.; Bent, S. F. Synthesis of Doped, Ternary, and Quaternary Materials by Atomic Layer Deposition: A Review. Chem. Mater. 2019, 31, 11421183.

(44) Elam, J. W.; Routkevitch, D.; Mardilovich, P. P.; George, S. M. Conformal Coating on Ultrahigh-Aspect-Ratio Nanopores of Anodic Alumina by Atomic Layer Deposition. Chem. Mater. 2003, 15, 35073517.

(45) Young, V. L.; Cox, D. F.; Davis, M. E. Metalorganic Chemical Vapor Deposition of Copper from Copper(II) Dimethylaminoethoxide. Chem. Mater. 1993, 5, 1701-1709.

(46) Becker, R.; Devi, A.; Weiß, J.; Weckenmann, U.; Winter, M.; Kiener, C.; Becker, H.-W.; Fischer, R. A. A Study on the Metal Organic CVD of Pure Copper Films from Low Cost Copper(II) Dialkylamino-2-Propoxides: Tuning the Thermal Properties of the Precursor by Small Variations of the Ligand. Chem. Vap. Deposition 2003, 9, 149-156.

(47) Judd, M. D.; Plunkett, B. A.; Pope, M. I. The Thermal Decomposition of Calcium, Sodium, Silver and Copper(II) Acetates. J. Therm. Anal. 1974, 6, 555-563.

(48) Sharrock, P.; Melník, M. Copper(II) Acetates: From Dimer to Monomer. Can. J. Chem. 1985, 63, 52-56.

(49) Afzal, M.; Butt, P. K.; Ahmad, H. Kinetics of Thermal Decomposition of Metal Acetates. J. Therm. Anal. 1991, 37, 10151023.

(50) Didonato, G. C.; Busch, K. L. A Mass Spectrometric Study of Copper(II) Acetate. Int. J. Mass Spectrom. Ion Processes 1986, 69, 6783.

(51) Edwards, D. A.; Hayward, R. N. Transition Metal Acetates. Can. J. Chem. 1968, 46, 3443-3446.

(52) Kirchner, S. J.; Fernando, Q.; Darby, D.; Dilts, J. A. Copper(I) Acetate. Inorg. Synth. 1980, DOI: 10.1002/9780470132517.ch16.

(53) Galwey, A. K. Thermal Reactions of Selected Solids Including Reactants That Melt during Chemical Change. J. Therm. Anal. 1994, 41, 267.

(54) Arroval, T.; Aarik, L.; Rammula, R.; Kruusla, V.; Aarik, J. Effect of Substrate-Enhanced and Inhibited Growth on Atomic Layer Deposition and Properties of Aluminum-titanium Oxide Films. Thin Solid Films 2016, 600, 119-125.

(55) Nilsen, O.; Karlsen, O. B.; Kjekshus, A.; Fjellvåg, H. Simulation of Growth Dynamics in Atomic Layer Deposition. Part II. Polycrystalline Films from Cubic Crystallites. Thin Solid Films 2007, 515, 4538-4549.

(56) Korzhavyi, P. A.; Soroka, I. L.; Isaev, E. I.; Lilja, C.; Johansson, B. Exploring Monovalent Copper Compounds with Oxygen and Hydrogen. Proc. Natl. Acad. Sci. U.S.A. 2012, 109, 686-689.

(57) Lutterotti, L.; Chateigner, D.; Ferrari, S.; Ricote, J. Texture, Residual Stress and Structural Analysis of Thin Films Using a Combined X-Ray Analysis. Thin Solid Films 2004, 450, 34-41.

(58) Kirfel, A.; Eichhorn, K. Accurate Structure Analysis with Synchrotron Radiation. The Electron Density in $\mathrm{Al}_{2} \mathrm{O}_{3}$ and $\mathrm{Cu}_{2} \mathrm{O}$. Acta Crystallogr., Sect. A: Found. Crystallogr. 1990, 46, 271-284.

(59) Putkonen, M.; Sajavaara, T.; Niinistö, L.; Keinonen, J. Analysis of ALD-Processed Thin Films by Ion-Beam Techniques. Anal. Bioanal. Chem. 2005, 382, 1791-1799.

(60) Knapas, K.; Ritala, M. In Situ Studies on Reaction Mechanisms in Atomic Layer Deposition. Crit. Rev. Solid State Mater. Sci. 2013, 38, 167-202.
(61) Potter, A. E.; Ritter, H. L. The Vapor Pressure of Acetic Acid and Acetic-D3 Acid-d. The Liquid Density of Acetic-D3 Acid-D. J. Phys. Chem. 1954, 58, 1040-1042.

(62) Biesinger, M. C.; Lau, L. W. M.; Gerson, A. R.; Smart, R. S. C. Resolving Surface Chemical States in XPS Analysis of First Row Transition Metals, Oxides and Hydroxides: Sc, Ti, V, Cu and $\mathrm{Zn}$. Appl. Surf. Sci. 2010, 257, 887-898.

(63) Biesinger, M. C. Advanced Analysis of Copper X-Ray Photoelectron Spectra. Surf. Interface Anal. 2017, 49, 1325-1334.

(64) McCafferty, E.; Wightman, J. P. Determination of the Concentration of Surface Hydroxyl Groups on Metal Oxide Films by a Quantitative XPS Method. Surf. Interface Anal. 1998, 26, 549564

(65) Yin, M.; Wu, C.-K.; Lou, Y.; Burda, C.; Koberstein, J. T.; Zhu, Y.; O’Brien, S. Copper Oxide Nanocrystals. J. Am. Chem. Soc. 2005, 127, 9506-9511.

(66) Wu, C.-K.; Yin, M.; O’Brien, S.; Koberstein, J. T. Quantitative Analysis of Copper Oxide Nanoparticle Composition and Structure by X-Ray Photoelectron Spectroscopy. Chem. Mater. 2006, 18, 60546058.

(67) Palkar, V. R.; Ayyub, P.; Chattopadhyay, S.; Multani, M. SizeInduced Structural Transitions in the $\mathrm{Cu}-\mathrm{O}$ and $\mathrm{Ce}-\mathrm{O}$ Systems. Phys. Rev. B 1996, 53, 2167-2170.

(68) Swanepoel, R. Determination of the Thickness and Optical Constants of Amorphous Silicon. J. Phys. E: Sci. Instrum. 1983, 16, $1214-1222$

(69) Sreemany, M.; Sen, S. A Simple Spectrophotometric Method for Determination of the Optical Constants and Band Gap Energy of Multiple Layer $\mathrm{TiO}_{2}$ Thin Films. Mater. Chem. Phys. 2004, 83, 169177.

(70) Jia, R.; Lin, G.; Zhao, D.; Zhang, Q.; Lin, X.; Gao, N.; Liu, D. Sandwich-Structured $\mathrm{Cu} 2 \mathrm{O}$ Photodetectors Enhanced by Localized Surface Plasmon Resonances. Appl. Surf. Sci. 2015, 332, 340-345.

(71) Kužel, R. The Effect of Oxygen on the Electric Conductivity of a Cuprous Oxide Single Crystal. Czech. J. Phys. 1961, 11, 133-140.

(72) Tapiero, M.; Zielinger, J. P.; Noguet, C. Photomemory Effect in $\mathrm{Cu}_{2} \mathrm{O}$ Single Crystals. Phenomenology and Interpretation. Phys. Status Solidi A 1976, 33, 155-166.

(73) Biccari, F. Defects and Doping in $\mathrm{Cu}_{2} \mathrm{O}$. Ph.D. Thesis, Sapienza University of Rome: Italy, 2009.

(74) Isseroff, L. Y.; Carter, E. A. Electronic Structure of Pure and Doped Cuprous Oxide with Copper Vacancies: Suppression of Trap States. Chem. Mater. 2013, 25, 253-265.

(75) Suntola, T. Atomic Layer Epitaxy. Thin Solid Films 1992, 216, $84-89$.

(76) Jokinen, J.; Keinonen, J.; Tikkanen, P.; Kuronen, A.; Ahlgren, T.; Nordlund, K. Comparison of TOF-ERDA and Nuclear Resonance Reaction Techniques for Range Profile Measurements of KeV Energy Implants. Nucl. Instrum. Methods Phys. Res., Sect. B 1996, 119, 533542 . 